\title{
Use of Electrophoretic Patterns of Proteins and Isozymes to Characterize Trichoderma Isolates from Cotton Roots Hussein, E. M. ${ }^{1}$; A. A. Aly ${ }^{1}$; A. A. El-Awamri ${ }^{2}$ and Marian M. Habeb ${ }^{1}$ ${ }^{1}$ Plant Pathology Research Institute, Agricultural Research Center, Giza, Egypt ${ }^{2}$ Botany Department, Faculty of Science, Ain Shams University, Cairo, Egypt
}

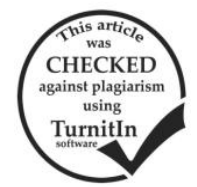

\section{ABSTRACT}

Proteins of 15 isolates of T. longbrachiatum and T. harzianum were compared by polyacrylamid gel electrophoresis (PAGE) and sodium dodecyl sulfate-polyacrylamide gel electrophoresis (SDS-PAGE). Gels were stained with silver nitrate. Protein banding patterns of the isolates were subjected to cluster analysis by the unweighted pair-group method based on arithmetic mean (UPGMA). Apart from T. harzianum isolates T6 in PAGE and T27 in SDS-PAGE, which occupied separate positions in the phenograms, it was possible to delineate the isolates of each species on the basis of the results of PAGE and SDS-PAGE. Peroxidase (EC 1.11.1.7) and esterase (EC 3.1.1.1) isozymes from mycelium and conidia of Trichoderma isolates were separated by PAGE, and the obtained banding patterns were visualized by using specific staining systems. Cluster analysis indicated that delineation of the isolates of each species was not possible on the basis of the electrophoretic patterns of peroxidase. On the contrary, patterns of esterase isozymes provided a reliable method for grouping the isolates of each species with the exception of T9 and T14 of T. longbrachiatum, which occupied separate positions in the phenogram.

\section{INTRODUCTION}

Biological control of root pathogens consists basically of encouraging the growth and activity of Trichoderma spp. (Stoppacher et al., 2006).

Tichoderma species are capable of producing a variety of antibiotics (Dennis and Webster, 1971) and hydrolytic enzymes (Geremia et al., 1993), which play key role in the interaction with pathogenic fungi and are necessary for successful antagonism.

\section{a. Protein electrophoresis:}

Protein electrophoresis has been widely used as a biochemical tool in fungal taxonomy. This is because amino acid sequences of polypeptides (components of proteins) are dependent on nucleotide sequences of their coding genes; therefore, an analysis of protein variation among fungal isolates by electrophoresis approximates an analysis of their genetic variation (Markert and Faulhaber, 1965). However, a problem with proteins as markers is the vast number, which can be generated from an organism. Faced with so much data, only sophisticated analysis can help to draw meaningful conclusions. The ready availability of computers has made numerical taxonomy more accessible and same later studies on fungi have proven useful (Manicom et al., 1990).

Aly et al. (1997) used PAGE and SDS-PAGE to characterize $F$. oxysporum, $F$. moniliforme, and $F$. solani isolated from cotton seedlings infected with damping-off. Delineation of isolates of each species was not possible on the basis of electrophoretic banding patterns of native proteins. On the contrary, banding patterns of SDSdissociated proteins proved a reliable method for grouping isolates for each species. Moreover, phylogenetic relationships between the resulting clusters matched that based on morphological taxonomy.

Aly et al. (2000) reported that electrophoretic banding patterns of dissociated proteins provided a reliable method for grouping the four Egyptian races of $F$. oxysporum f.sp. ciceris.

Aly et al. (2001) compared protein patterns of five isolates of $F$. oxysporum f.sp. vasinfectum (FOV) and a nonpathogenic isolate of $F$. oxysporum by PAGE and SDS-PAGE. Both PAGE and SDS-PAGE could not be used to distinguish the highly pathogenic isolates of FOV.

Salama et al. (2002) used SDS-PAGE to study the phylogenetic relationships among six Trichoderma spp. isolated from the Egyptian soil. Cluster analysis divided the six aggregate species into two groups. The first one included only $T$. koningii aggregate species, whereas the second group was subdivided into two subgroups, the first one included T. harzianum, T. hamatum, T. reesei, and $T$. pseudokoningii and the second one included only $T$. viride. b. Isozyme electrophoresis:

Enzymatic properties of isozymes are similar, if not identical; however, isozymes slightly differ in their amino acid sequences. Only those isozymes with amino acid compositions of different net charge, or those that result in large differences in the shape of an enzyme, can by differentiated by electrophoresis (Bonde et al., 1993).

Vagujfalvi and Szecsi (1994) collected Fusarium spp. from 30 localities and different parts (roots, stalks, and ears) of maize. They used polyacrylamide slab gel electrophoresis of protein extracts of $F$. moniliforme, $F$. proliferatum, and $F$. subglutinans to obtain esterase (EST) zymograms. The sites of EST activity were recorded, and the $\mathrm{R}_{\mathrm{f}}$ values were calculated. Isolates of $F$. moniliforme were divided into two zymogram types (type I and type II) based on EST isozyme patterns. EST zymogram type II was very similar to patterns of $F$. proliferatum. Their data suggested that these isolates are actually $F$. proliferatum.

The present study was initiated to determine whether Trichoderma isolates from cotton roots (Table 1) can be characterized by their electrophoretic protein banding patterns separated by PAGE and SDS-PAGE.

Table 1. Geographic origins of Trichoderma spp. Isolated from cotton seedlings.

\begin{tabular}{lcc}
\hline Isolate code & Identification & Geographic origin \\
\hline T3 & T. harzianum & Daqahliya, Simbellawain \\
T4 & T. longibrachiatum & Assiut, Assiut \\
T5 & T. longibrachiatum & Assiut, Assiut \\
T6 & harzianum & Daqahliya, Simbellawain \\
T9 & T. longibrachiatum & Unknown \\
T10 & T. harzianum & Daqahliya, Simbellawain \\
T14 & T. longibrachiatum & Giza, Giza \\
T18 & T. longibrachiatum & Minufiya, Minouf \\
T23 & T. harzianum & Gharbiya, \\
T27 & El Mahalla El Kobra \\
T29 & T. harzianum & Gharbiya, \\
T31 & T. harzianum & El Mahalla El Kobra \\
T38 & T. longibrachiatum & Daqahliya, Simbellawain \\
& Minufiybellawain \\
T39 & T. longibrachiatum & Shibeen El Kom \\
T42 & T. longibrachiatum & Minufiya, \\
& & Shibeen El Kom \\
& & Giza, Giza \\
\hline
\end{tabular}


Isozymes of peroxidase and esterase separated by PAGE were also tested for ability to differentiate between the isolates.

\section{MATERIALS AND METHODS}

\section{Extraction of proteins from Trichoderma isolates}

Proteins were prepared according to Guseva and Gromova (1982), Rataj-Guranowska et al. (1984), and Hussein (1992). The protein content in supernatant was estimated according to Bradford (1976) by using bovine serum albumin as a standard protein. If protein concentration was low, protein would be precipitated from the clarified supernatant by adding ammonium sulphate at $70 \%$ of saturation $(60 \mathrm{~g} / 100 \mathrm{ml})$ then kept in the refrigerator for 30 hrs. Pellets, collected by centrifugation at $11,000 \mathrm{rpm}$ for 30 min., were resuspended in phosphate buffer $\mathrm{pH} 8.3$ and subjected to dialysis for $24 \mathrm{hrs}$. against the buffer and centrifugation at $11,000 \mathrm{rpm}$ for $30 \mathrm{~min}$. Protein was estimated in the obtained supernatant.

\section{Electrophoresis of native protein (PAGE)}

Electrophoresis was conducted at $10 \mathrm{oC}$ for $4 \mathrm{hrs}$. in a $7.5 \%$ polyacrylamide gel with a 3.5 stacking gel, at 15 and $30 \mathrm{~mA}$, respectively, until the dye band reached the bottom of the separating gel (Davis, 1964). Electrophoresis was performed in a vertical slab mold $(16 \times 18 \times 0.15 \mathrm{~cm})$. Gels were stained with silver nitrate for the detection of protein bands (Sammons et al., 1981).

3. Electrophoresis of dissociated protein (SDS-PAGE)

Electrophoresis (Laemmli, 1970) and staining of gels were carried out as previously mentioned in PAGE.

\section{Electrophoresis of isozymes}

Electrophoresis of isozymes was carried out as previously mentioned in PAGE; however, gels were stained according to Manchenko (1994) for the detection of isozymes of esterase (EC.3.1.1.1) and peroxidase (EC.1.11.1.7).

\section{Gel analysis}

A gel documentation system (Advanced American Biotechnology 1166 E.Valencia Dr. Unit 6 C, Fullerton CA 92631) was used to document the results of electrophoresis and to cluster the electrophoretic patterns of proteins and isozymes by the UPGMA.

\section{RESULTS}

\section{Electrophoresis of native protein (PAGE)}

Fig. 2 showed the phenogram constructed based on similarity levels (SLs) generated from cluster analysis of electrophoretic banding patterns of native (undissociated) proteins shown in Fig. 1.

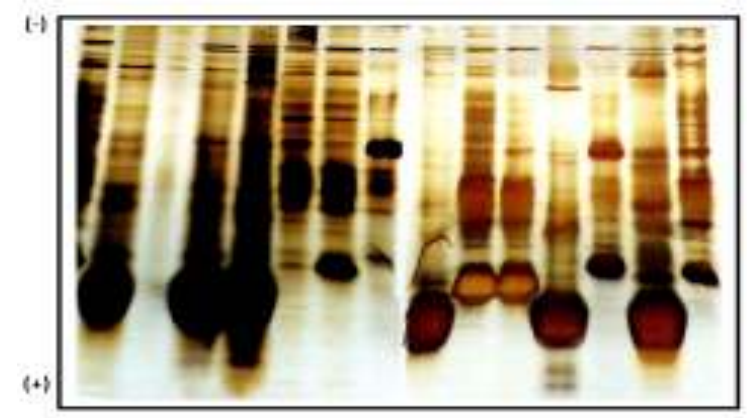

Fig. 1. Protein bands obtained by PAGE from 15 isolates of Trichoderma spp. Isolates in lanes from left to right were T18, T39, T38, T42, T4, T5, T14, T9, T27, T23, T29, T10, T3, T31, and T6.

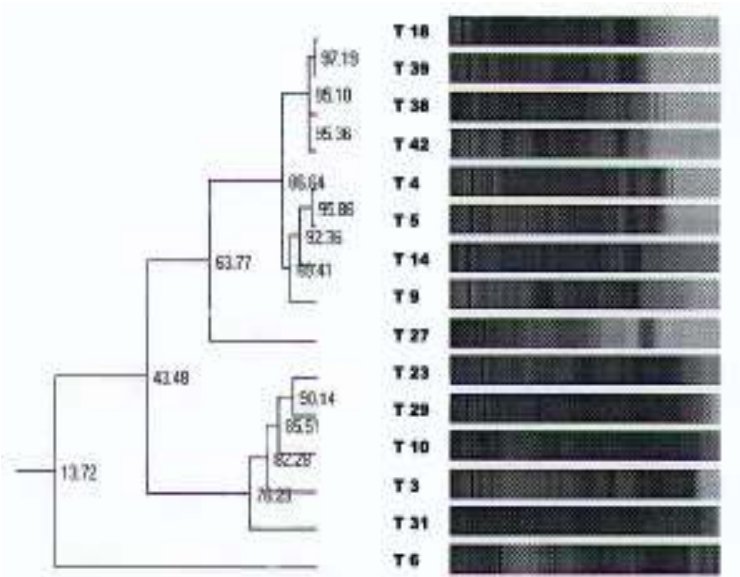

Fig. 2. Phenogram of electrophoretic protein bands obtained by PAGE from 15 isolates of Trichoderma spp.

The greater the SL, the more closely the isolates were in their protein composition. In this phenogram, all the isolates of $T$. longibrachiatum were clustered within the SL $86.64 \%$, which illustrated a remarkable overall SL among the tested isolates. On the other hand, only five isolates of $T$. harzianum were placed in a single cluster within the SL $76.29 \%$. A noteworthy peculiarity in the phenogram was the behaviour of the isolates no $_{\mathrm{s} .} \mathrm{T} 27$ and T6 of $T$. harzianum, which were remotely related to the other isolates of T. harzianum.

2. Electrophoresis of dissociated protein (SDS-PAGE)

The dendrogram shown in Fig. 4 was constructed based on SLs generated from cluster analysis of electrophoretic banding patterns of dissociated proteins shown in Fig. 3. The isolates in the dendrogram formed two large taxonomic groups within the SL $31.41 \%$. The first group ( $\mathrm{SL}=48.75 \%$ ) included all the isolates of $T$. longibrachiatum, while the second group included only 6 isolates $(85.71 \%)$ of $T$. harzianum within the SL $41.30 \%$. Surprisingly, isolate no. T27 of T. harzianum formed a separate cluster remotely related to the latter group.

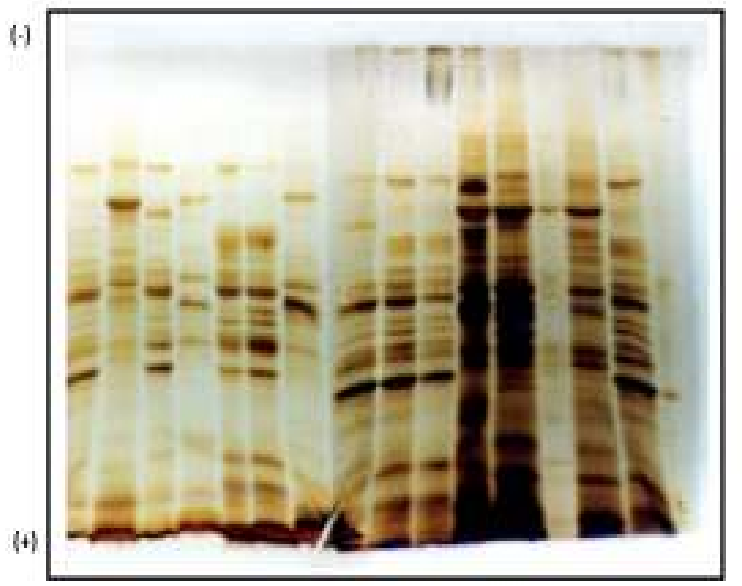

Fig. 3. Protein bands obtained by SDS-PAGE from 15 isolates of Trichoderma spp. and a protein marker (M). Isolates in lanes from left to right were T27, T6, T10, T3, T31, T29, T23, T9, T5, T4, T14, T42, $\mathrm{T} 38, \mathrm{T39}, \mathrm{T} 18$, and a protein marker. 


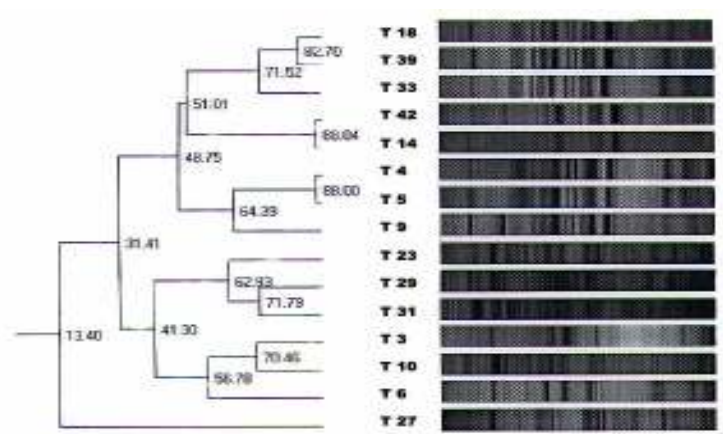

Fig. 4. Phenogram of electrophoretic protein bands obtained by SDS-PAGE from 15 isolates of Trichoderma spp.

\section{Electrophoresis of isozymes}

1. Esterase isozymes

The dendrogram shown in Fig. 6 was constructed based on SLs generated from cluster analysis of electrophoretic esterase isozyme patterns shown in Fig. 5.

The isolates in the dendrogram formed two large taxonomic groups within the SL 51.34\%. The first group ( $\mathrm{SL}=77.25 \%$ ) included all the isolates of $T$. harzianum, while the second group included only six isolates $(75 \%)$ of T. longibrachiatum within the SL $77.56 \%$. Surprisingly, isolates $\mathrm{no}_{\mathrm{s} .} \mathrm{T} 9$ and T14 of T. longibrachiatum formed a separate cluster at SL $47.46 \%$, this cluster was remotely related to the latter group.

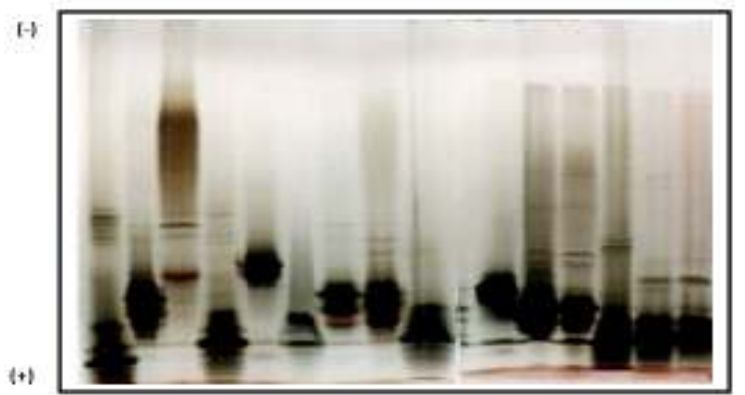

Fig. 5. Esterase isozyme bands obtained by PAGE from 15 isolates of Trichoderma spp. Isolates in lanes from left to right were T14, T9, T18, T5, T4, T42, T39, T38, T23, T6, T10, T3, T31, T29, and T27.

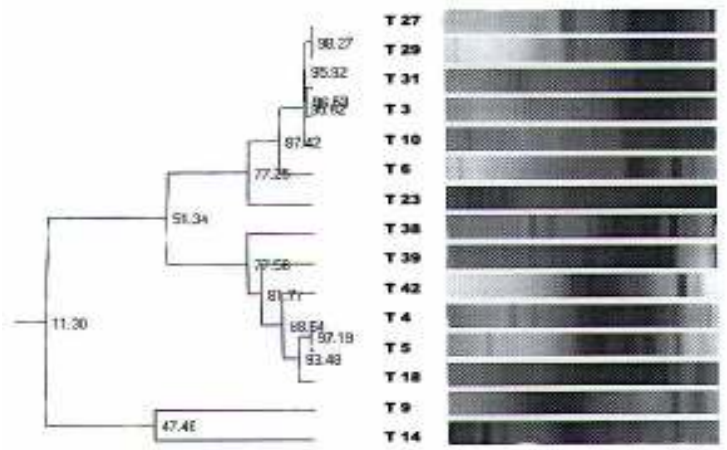

Fig. 6. Phenogram of electrophoretic esterase isozyme bands obtained by PAGE from 15 isolates of Trichoderma spp.

\section{Peroxidase isozymes}

The dendrogram shown in Fig. 8 was constructed based on SLs generated from cluster analysis of electrophoretic peroxidase isozyme patterns shown in Fig. 7. In this phenogram, the delineation of isolates of $T$. harzianum or $T$. longibrachiatum was not possible on the basis of the results of cluster analysis of peroxidase isozyme patterns.

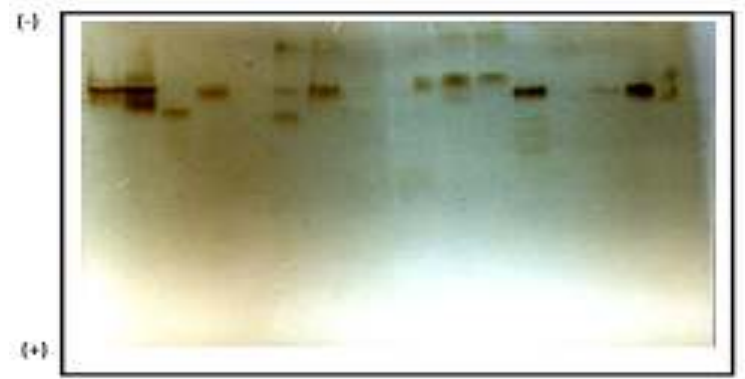

Fig. 7. Peroxidase isozyme bands obtained by PAGE from 15 isolates of Trichoderma spp. Isolates in lanes from left to right were T14, T31, T23, T39, T42, T38, T10, T5, T3, T6, T29, T27, T9, T4, and T18.
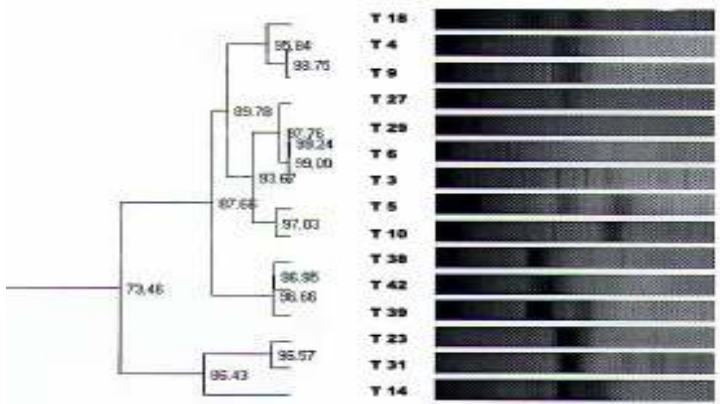

Fig. 8. Phenogram of electrophoretic peroxidase isozyme bands obtained by PAGE from 15 isolates of Trichoderma spp.

\section{DISCUSSION}

Apart from T. harzianum isolates T6 in PAGE and T27 in SDS-PAGE, which occupied separate positions in the phenograms, it was possible to delineate the isolates of each species on the basis of the results of PAGE and SDS-PAGE. However, I am aware that the number of isolates that belonged to each species and were available for study was too limited to arrive unequivocal conclusions regarding the suitability of protein electrophoresis to distinguish isolates of $T$. longibrachiatum from those of $T$. harzianum. Despite this limitation, certain conclusions could be drawn. The amount of variation in electrophoretic banding patterns is adequate for the application of cluster analysis, therefore, the refinement of PAGE and SDS-PAGE employed in the present work by analyzing more isolates of each species, in combination with cluster analysis of the resulting protein profiles, could provide a reliable method for (1) rapid grouping of isolates; (2) allocation of unknown isolate to a group and its possible identification; (3) storage of large numbers of patterns in data banks for reference; (4) information on epidemiological spreading of isolates (Kerster and De Ley, 1975).

In the present study, in an agreement with Hall (1967), we stress that successful use of PAGE and SDSPAGE as biochemical aids in Trichoderma taxonomy requires that growth, extraction, and electrophoretic procedures must be carried out under standardized rigorously controlled conditions.

Electrophoresis of isozymes is widely used in fungal taxonomic studies because catalytic activity of enzymes can be measured in cell-free systems with precision and ease (Hall, 1967). 
Previous studies indicated that isozyme analysis was a useful supplement to morphological analysis in Trichoderma taxonomy, particularly when data were analyzed by phylogentic methods (Zamir and Chet, 1985; Stasz et al., 1989 and Leuchtmann et al., 1996).

In the present study, delineation of the isolates of each species was not possible on the basis of the electrophoretic patterns of peroxidase isozymes. On the contrary, patterns of esterase isozymes provided a reliable method for grouping the isolates of each species with the exception of T9 and T14 of T. longibrachiatum, which occupied separate positions in the phenogram.

\section{REFERENCES}

Aly, A.A., E.M. Hussein, S.M.E. Zayed, and H.A. Eisa. 2001. Lack of relationships between protein electrophoretic patterns of Fusarium oxysporum f.sp. vasinfectum isolates and their pathogenicity of cotton. J. Agric. Sci. Mansoura Univ. 26:4886-4896.

Aly, A.A., M.A. Tag El-Din, E.M. Hussein, A.Z.A. Ashour, and S.M. Nasr. 1997. Separation by protein electrophoresis of three species of Fusarium isolated from cotton. J. Agric. Sci. Mansoura Univ. 22:123-135.

Aly, A.A., S.A. Omar, and M.R. Omar. 2000 . Separation of four races of Fusarium oxysporum f.sp. ciceris by protein electrophoresis. Minufiya J. Agric. Res. 25:1320.

Bonde, M.R., J.A. Micales, and G.L. Peterson. 1993. The use of isozyme analysis for identification of plant-pathogenic fungi. Plant Dis. 77:961-968.

Bradford, M.M. 1976. A rapid and sensitive method for the quantification of protein utilizing the principle of protein-dye binding. Anal. Biochem. 72:248-254.

Davis, B.J. 1964. Disc electrophoresis. II. Method and application to human serum proteins. Ann. New York Acad. Sci. 121:404-427.

Dennis, G and J. Webster. 1971. Antagonistic properties of species groups of Trichoderma. I. Production of nonvolatile antibiotics. Trans-Brit. Mycol. Soc. 57:25-39.

Geremia, R., G.H. Goldman, D. Jacobs, W. Ardiles, S.B, Vila, M. Van Montagu, and A. Herrera-Estrella. 1993. Molecular characterization of the proteinase encoding gene, prb1 related to mycoparasitism by Trichoderma harzianum. Mol. Microbiol. 8: 603-613.

Guseva, N.N. and B.B. Gromova. 1982."Chemical and Biochemical Methods for Studying Plant Immunity". (In Russian). All Union Institute of Plant Protection, Leningrad, U.S.S.R.

Hall, R. 1967. Protein and catalase isozymes from Fusarium solani and their taxonomic significance. Aust. J. Biol. Sci. 20:419-428.
Hussein, E.M. 1992. Biochemical and serological studies for determining susceptibility of cotton cultivars to Fusarium oxysporum f.sp. vasinfectum. (In Russian). Ph.D. Thesis, All Union Institute of Plant Protection, Leningrad, U.S.S.R.

Kerster, S. and J. De Ley. 1975. Identification and grouping of bacteria by numerical analysis of their electrophoretic protein patterns. J. General Microbiol. 87:333-342.

Laemmli, U.K. 1970. Cleavage of structural proteins during assembly of the head of bacteriophage T4. Nature 227:680-685.

Leuchtmann, A., O. Petrini, and G. Samuels. 1996. Isozyme subgroups in Trichoderma section Longbrachiatum. Mycologia 88: 384-394.

Manicom, B.Q., M. Bar-Joseph, and J.M. Kotze. 1990. Molecular methods of potential use in the identification and taxonomy of filamentous fungi, particularly Fusarium oxysporum. Phytophylactica 22:223-239.

Markert, C.L. and I. Faulhaber. 1965. Lactate dehydrogenase isozyme patterns of fish. J. Exp. Zool. 159:319-332.

Rataj-Guranowska, M., I. Wiatroszak, and L. Hornok. 1984. Serological comparison of two races of Fusarium oxysporum f.sp. lupini. Phytopathol. Z. 110:221-225.

Salama, S.A., G.A. Amer, and S.M. El-Desouky. 2002. Phylogenetic relationships among Trichoderma species using molecular markers to assess their efficiency as biocontrol agents. Egypt. J. Genet. Cytol. 31:253-266.

Sammons, D.W., L.D. Adams, and E.E. Nishizawa. 1981. Ultrasensitive silver based color staining of polypeptides in polyacrylamide gels. Electrophoresis 2:135.

Stasz, T.E., K. Nixon, G. Harman, and N.F. Weeden. 1989. Evaluation of phonetic species and phylogenetic relationships in the genus Trichoderma by cladistic analysis of isozyme polymorphism. Mycologia 81:391403.

Stoppacher, N., B. Reithner, S. Zeilinger, K. Brunner, R. L. Mach, R. Krska, and R. Schuhmacher. 2006. Screening for atroviridins, neoatroviridins, and harzianins in culture samples of Trichoderma atroviride using LCMS/MS. P8 In: $9^{\mathrm{TH}}$ international workshop on Trichoderma and Gliocladium. Book of Abstracts (R. L. Mach and S. Zeilinger, eds.). Vienna University of Technology, Vienna, Austria.

Vagujfalvi, A. and A. Szecsi. 1994. Esterase isozyme variation among Fusarium moniliforme, $F$. prolifertatum, and $F$. subglutinans. Acta Phytpathologica Entomologica Hungarica 29:231-238.

Zamir, D. and I. Chet. 1985. Application of enzyme electrophoresis for the identification of isolates in Trichoderma harzianum. Can. J. Microbiol. 31:578580.

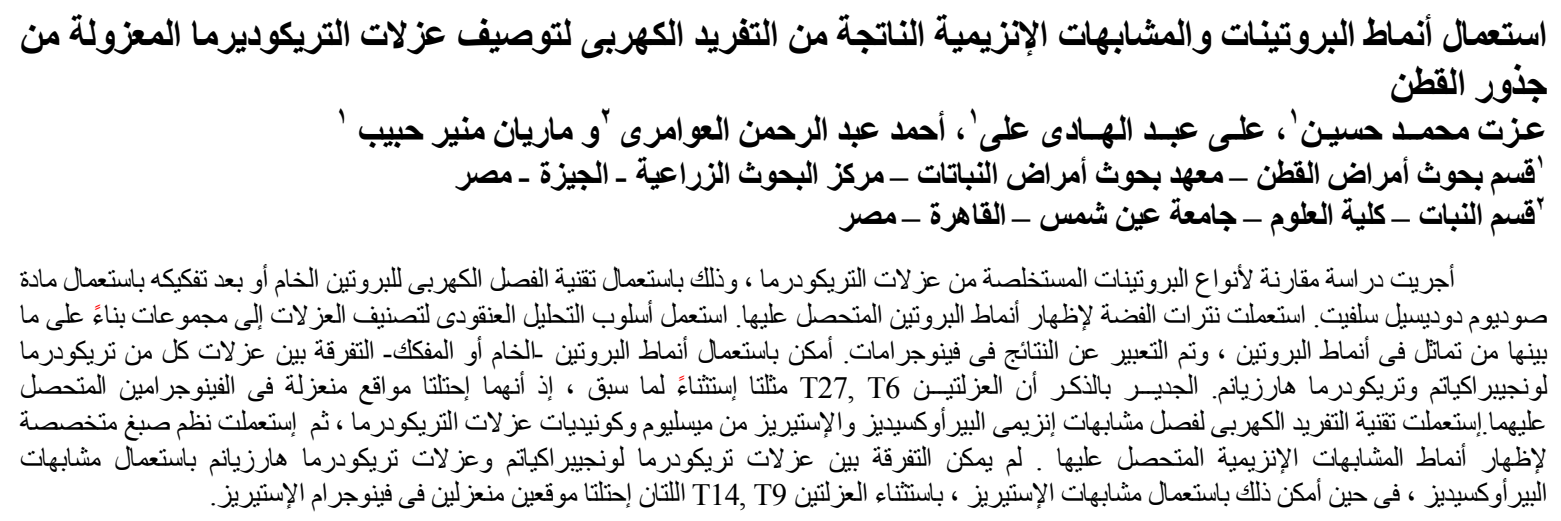

